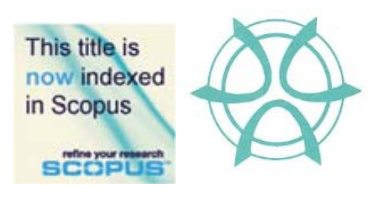

PLANNING MALAYSIA:

Journal of the Malaysian Institute of Planners

VOLUME 16 ISSUE 2 (2018), Page 323 - 333

\title{
A REVIEW OF IBS IMPLEMENTATION IN MALAYSIA AND SINGAPORE
}

\author{
Asiah Abdul Rahim ${ }^{1}$ \& Sara Latif Qureshi ${ }^{2}$ \\ ${ }^{1,2}$ Kulliyyah of Architecture and Environmental Design, \\ INTERNATIONAL ISLAMIC UNIVERSITY MALAYSIA
}

\begin{abstract}
This paper is a review of IBS implementation in Malaysia and Singapore. It investigates the limitations and opportunities in implementation of IBS in Malaysia and Singapore. In Malaysia, Construction Industry Development Board (CIDB) defines Industrialised Building System (IBS) as a construction technique in which components are manufactured in a controlled environment (either onsite or offsite), then transported, positioned and installed into a structure with less additional onsite works. Content analysis is the method adopted in this study. Data is collected from books, journal articles, annual reports and newspaper articles. Studies show that IBS contributes many benefits including labour reduction, cleaner and neater sites, easy installation, fast completion, enhancement of quality finished products and flexibility. Construction industries in countries like Singapore and Malaysia have shifted the construction methods from conventional to prefabrication. In Malaysia, Construction Industry Development Board (CIDB) is still promoting IBS in the private sector, whereas, government sector has successfully adopted IBS. However, in Singapore, Housing and Development Board (HDB) has implemented prefabrication in its construction industry. IBS has many benefits but with these benefits there are some limitations and hindrances as IBS is not widely adopted. This study highlights the benefits and challenges to overcome for the improvement in the implementation of IBS.
\end{abstract}

Keywords: industrialized building system (IBS), prefabrication, construction, Malaysia, Singapore 
Asiah Abdul Rahim \& Sara Latif Qureshi

A Review of IBS Implementation in Malaysia and Singapore

\section{INTRODUCTION}

Malaysia's population reached 32 million in 2017 (Bernama, 2017) and is estimated to grow by 2 million every five years (CIDB, 2016). The residents' population in Singapore was 3.93 million in 2016 and rose $0.8 \%$ to 3.97 million at the end of June 2017 (Singapore Department of Statistics, 2017). As the population increases, the demand of housing increases. According to Ismail and Rahim (2009), a system architecture which takes the advantage of new technology could change entire construction industry. However, the conventional method of construction is not efficient enough to cope with the increasing demand for housing. The construction industry has shifted its attention to mass production and prefabrication construction methods to fulfil the rapidly growing need for housing. This strategy motivated Malaysian construction industry to analyze the industries from various countries who have achieved the implementation of prefabrication technology such as United Kingdom (UK), United States (US), Australia, Hong Kong and Singapore (Seik, 2001; NAHB Research Center, 2002; Jaillon \& Poon, 2009; Blismas \& Wakefield, 2009; Lovell \& Smith, 2010; Azman, Majid, Ahamad, \& Hanafi, 2011). Prefabrication is not merely focussed on mass production but also delivers a unique product using a systematic approach (Gardiner, 2008).

One of the second largest economic sectors in many developing countries is the construction industry (Preece, Pheng, Padfield, \& Papargyropoulou, 2011). The three broad activities in an industry namely residential building, nonresidential building and engineering construction. The main factors which play important roles in the residential building sector are the Government policies, the availability of skilled labour and building material resources. Mass House Building Projects (MHBPs) and a sustainable building model for developing countries have introduced initiatives to provide affordable building structures (Ahadzie, Proverbs, \& Olomolaiye, 2008).

A sustainable construction is described as a subset of sustainable development, which includes design, tendering, site planning, and organization, material selection, recycling, and waste minimization (Langston \& Ding, 2001). Whereas, a conventional construction method is the result of many factors which can be technological, social or financial (Rahim, Hamid, Zen, Ismail, \& Kamar, 2012). Conventional construction involves complete on-site work and is unsustainable as it is associated with poor quality and productivity, high risk of worker safety and high dependency on labours. Whereas prefabricated construction or IBS (Industrialised Building System) is a construction method which involves the off-site manufacturing of components in a factory controlled environment which are then transported and assembled into a structure with limited work on construction site. IBS is a sustainable method as the buildings are constructed in a short time span with significantly reduced on-site activities, hence resulting in tremendous savings to the stakeholders. According to Ismail 
and Rahim (2009), factory manufactured components are easy to assemble on site, use less labour, faster to construct and are of high quality. The method is beneficial in terms of cost saving, minimizing on-site wastage, safety, high quality work, cleanliness and neatness of on-site work, reduces dependency on manual foreign labours (Pan, Gibb, \& Dainty, 2012), provides easy installation and flexible (Aziz \& Razuan, 2003).

\section{METHODOLOGY}

The method adopted in this study is content analysis. Data is collected from books, newspaper articles, annual reports and journals including Construction Industry Development Board (CIDB) reports, Malaysian Construction Research Journal (MCRJ) by CREAM (CIDB), Population Trends by Department of Statistics Singapore, Circular on Amendments to Building Controls (Buildability and Productivity) by Building and Construction Authority (BCA) Singapore and Australian Journal of Basic and Applied Sciences.

\section{BACKGROUND STUDY}

\section{Malaysia}

IBS in Malaysia has been initiated since 1960s to overcome the shortage of houses. However the application of IBS was at infancy and not fully adopted. In late 1960s and early 1970s, some of the international IBS systems were introduced but these systems were found to be incompatible with the climatic condition in Malaysia hence resulted in the closure the precast concrete factories and conventional method had still to be applied (Hamid, Kamar, Zain, Ghani, \& Rahim 2008). In some cases, the budget was exceeded, targeted completion dates were not achieved, and the quality was not always up to expectation. Apart from encouraging the use of IBS in Malaysia, it is the government's objective to dwindle the dependency on foreign labour and save country's loss in foreign exchange in the Malaysian construction industry (Hamid et al., 2008; Hussein 2007). However, in 1999, due to lack of local skilled workers and overflow of unskilled foreign workers, the country recognized that use of IBS is the only solution to overcome these issues. The first IBS strategic plan was announced followed by two IBS "Roadmaps" i.e. 2003-2010 and 2011-2015 (CIDB, 2016). Since then, it is mandatory for government projects to comprise of at least $70 \%$ of IBS components (Khalil, Aziz, Hassim, \& Jaafar, 2016). However, IBS is still not widely implemented in private sector. Therefore, the main issues are still unsolved despite the initiatives by the government using IBS system.

Many countries such as Singapore have adopted the IBS or prefabrication and its benefits have been well-documented. IBS is then recognised as a complete process system of construction which includes the manufacturing of almost all 
Asiah Abdul Rahim \& Sara Latif Qureshi

A Review of IBS Implementation in Malaysia and Singapore

the component structures at a place other than the main site. The components are then transported and assembled to achieve high quality works with the reduction in completion time of the projects. Haroon, Rahman and Hanid (2009) define IBS or industrialised building system as the concept of mass production of quality building. However, Abdullah and Egbu (2009) define IBS as a method of construction developed by human investment in innovation and on reconsidering the best ways of construction work deliveries grounded on the level of industrialization. Whereas, Kamar et. al (2009) create a conceptual definition of IBS as an innovative process of building construction which uses the idea of mass-production of industrialised systems, produced at the industry or on-site within controlled environments, executed in proper coordination with rigorous planning and integration. Yunus and Yang (2011) highlights five standard characteristics of IBS i.e., prefabrication, offsite production, mass production, standardized components and design using modular coordination.

Malaysia's entire domestic construction labour force comprises of $25 \%$ foreign workers compared to an average of $13 \%$ in all other sectors (CIDB, 2016). Foreign workers levy in the manufacturing and construction sectors has been doubled from RM1,250 to RM2,500, a way to reduce over-reliance on low skilled foreign labour (CIDB, 2016). Khalil et al. (2016) found that the implementation of IBS in construction industry in Malaysia is less due to the unwillingness of the stakeholders because they are not convinced with the IBS system. The government aims to make it compulsory for the contractors to implement IBS by the year 2020. However, the move faces various challenges. A survey conducted by CIDB shows that the implementation of IBS by the private sector is still deficient around $15 \%$ and the government aims it to be higher about $70 \%$ (Yunus, 2017). One of the issues raised by the contractors is the lack of economies of scale. The contractor has to incur high initial costs for lifting and transporting the prefabricated components to the construction site (Yunus, 2017).

\section{SINGAPORE}

Many countries, including Singapore, at different levels of development, have recently formulated long-term plans to improve their construction industries. Singapore has a successful construction industry development agency which was formed in 1984 initially as Construction Industry Development Board (CIDB) and became Building and Construction Authority (BCA) in 1999 (Ofori, 2000). BCA is a government agency. In Malaysia, most of the housing are funded and developed by the private developers. However, in Singapore, the government develops most of the residences. Housing and Development Board (HDB) manages the Public accommodation in Singapore. Depending on the end-users needs, there are several options for Singapore homeowners. There are three most popular types of residential units in high-rise buildings in Singapore, namely, BTO (Built-to-Order), DBSS (Design, Build and Sell Schemes) and EC 
PLANNING MALAYSIA

Journal of the Malaysia Institute of Planners (2018)

(Executive Condominium). HDB offers BTO flats for sale which are public housing flats, private developers build DBSS which are also public housing flats and EC is one that is constructed and sold by private developers. Comparing costs, BTOs (the housing by HDB) are the most affordable than the other two, whereas ECs are the most expensive option.

Singapore experienced failures in the early stage of adoption of prefabrication technology (Thanoon, Peng, Kadir, Jaafar, \& Salit, 2003). The increasing demand of apartments in the early 1960s prompted the Housing and Development Board (HDB) of Singapore to adopt the IBS concept. Because of the critical need, the HDB launched the first prefabricated method of construction in 1963 using a trademarked French large panel and fabrication system on 10 blocks of standard 16 storey flats. However the project faced many technical and management issues and had to be completed by the conventional method (Malaysia Equity Research, 2014). Then, in 1973, HDB took initiatives to reattempt the IBS. In 1979 HDB introduced significant innovations in new building systems which includes Ferro-cement cladding system, prefabricated bathroom units (PBUs), precast pre-stressed composite floor system, architectural precast facades as well as pre-cut and pre-bend reinforcement bars (Malaysia Equity Research, 2014)

Singapore is now moving its concern toward PPVC (Prefabricated Prefinished Volumetric Construction). It is a construction method whereby freestanding volumetric modules (complete with finishes for walls, floors and ceilings) are manufactured and assembled by fabrication method and then installed under building works (BCA, 2015). The use of PPVC is mandatory for selected no-landed residential Government Land Sale (GLS) sites from 1" Nov 2014 (BCA, 2015). HDB announced that by 2019, 35\% of newly launched housing board projects will be built using PPVC and all BTO flats will be prefitted with pre-assembled bathroom units with copper piping, partial tiling, window frames and waterproofing systems ("HDB to expand use of prefabrication", 2017).

\section{ADVANTAGES AND LIMITATIONS IN IMPLEMENTATION OF IBS}

Mohammad, Baharin, Musa and Yusof (2016) found that modular system can reduce construction time and wastage but at the same time high initial costs and lack of technical expertise are the major hindrances to the implementation of IBS. Since IBS is facing many issues such as poor quality and lack of skill and technology, the focus should be on improving the use of IBS rather than maximizing its use (Gibb, 2001). Following are the advantages (Table 1) and the limitations (Table 2) categorized in the form of tables including the findings, authors and years. 
Asiah Abdul Rahim \& Sara Latif Qureshi

A Review of IBS Implementation in Malaysia and Singapore

Table 1: Advantages of IBS

\begin{tabular}{|c|c|c|c|}
\hline No. & Advantages & Findings & Authors \\
\hline 1. & Time saving & $\begin{array}{l}\text { IBS or prefabrication method is } \\
\text { good as it reduces construction } \\
\text { time. }\end{array}$ & $\begin{array}{l}\text { Marsono et al., 2006; } \\
\text { Rahim \& Ismail, 2011; } \\
\text { Koenigsberger, 1986; } \\
\text { Thanoon et al., 2003 }\end{array}$ \\
\hline 2. & $\begin{array}{l}\text { Quality } \\
\text { improvement }\end{array}$ & $\begin{array}{l}\text { IBS will produce better quality } \\
\text { products as it promises high level } \\
\text { of expertise throughout the } \\
\text { industry }\end{array}$ & $\begin{array}{l}\text { Azman et al., 2010; } \\
\text { CIDB, 2003; Din, } 1984\end{array}$ \\
\hline 3. & $\begin{array}{l}\text { Labour } \\
\text { reduction }\end{array}$ & $\begin{array}{l}\text { Reduces labour on site, involves } \\
\text { higher mechanization due to } \\
\text { repeatability process. }\end{array}$ & $\begin{array}{l}\text { Azman et al., 2010; } \\
\text { Warszawski, 1999; } \\
\text { Koenigsberger, } 1986\end{array}$ \\
\hline 4. & $\begin{array}{l}\text { Reduction of } \\
\text { remittances } \\
\text { by foreign } \\
\text { labour }\end{array}$ & $\begin{array}{l}\text { Reduces the remittances by } \\
\text { foreign labours. }\end{array}$ & Bernama, 2006 \\
\hline 5. & $\begin{array}{l}\text { Cost } \\
\text { reduction }\end{array}$ & $\begin{array}{l}\text { IBS can be cheaper than using } \\
\text { conventional methods as it } \\
\text { reduces labour cost, in addition to } \\
\text { this, the repetitive use of system } \\
\text { formwork provides significant } \\
\text { cost saings. }\end{array}$ & $\begin{array}{l}\text { Haroon et al., 2009; } \\
\text { Gann, 1996; Bing et al., } \\
2001\end{array}$ \\
\hline 6. & $\begin{array}{l}\text { Efficient } \\
\text { construction } \\
\text { process and } \\
\text { higher } \\
\text { productivity }\end{array}$ & $\begin{array}{l}\text { IBS will help to enhance } \\
\text { efficiency of construction process } \\
\text { allowing high productivity. }\end{array}$ & CIDB, 2004 \\
\hline 7. & $\begin{array}{l}\text { Wastage } \\
\text { reduction }\end{array}$ & $\begin{array}{l}\text { IBS offers minimum wastage and } \\
\text { less site materials as it enables } \\
\text { offsite or prefabricated } \\
\text { components manufactured at } \\
\text { factories, thus resulting in neater } \\
\text { and cleaner environment. }\end{array}$ & CIDB, 2003 \\
\hline 8. & $\begin{array}{l}\text { Flexible } \\
\text { design }\end{array}$ & $\begin{array}{l}\text { IBS allows flexibility in design of } \\
\text { precast elements as well as in } \\
\text { construction so that different } \\
\text { systems may produce their own } \\
\text { prefabrication } \\
\text { methods. }\end{array}$ & Omar, 2000 \\
\hline 9. & $\begin{array}{l}\text { Adverse } \\
\text { weatherproof } \\
\text { construction }\end{array}$ & $\begin{array}{l}\text { Because of the manufacture of } \\
\text { components in a factory } \\
\text { controlled environment, the } \\
\text { construction operation is not }\end{array}$ & Thanoon et al., 2003 \\
\hline
\end{tabular}


PLANNING MALAYSIA

The implementation of IBS is still deficient in the construction industry compared to the conventional method. Due to some previous lowquality IBS construction projects, there are some negative perceptions of different parties involved that lead to the limitations in the use of IBS as highlighted in Table.2.

Table 2: Limitations in IBS implementation

\begin{tabular}{|c|c|c|c|}
\hline No. & Limitations & Findings & Authors \\
\hline 1. & Time & $\begin{array}{l}\text { Delay due to improper planning and } \\
\text { conventional procurement approach. }\end{array}$ & $\begin{array}{l}\text { Mohammad et al., } \\
2016 \\
\end{array}$ \\
\hline 2. & Skills shortage & $\begin{array}{l}\text { Unskilled labours in IBS systems, lack } \\
\text { of technical expertise. }\end{array}$ & $\begin{array}{l}\text { Mohammad et al., } \\
2016 \\
\end{array}$ \\
\hline 3. & Poor Quality & $\begin{array}{l}\text { Previous IBS projects were of low } \\
\text { quality and high construction costs. }\end{array}$ & $\begin{array}{l}\text { Haroon et al., } \\
\text { 2009; Mohammad } \\
\text { et al, } 2016 \\
\end{array}$ \\
\hline 4. & Cost & Cost overrun/ high initial costs & $\begin{array}{l}\text { Mohammad et al., } \\
2016 \\
\end{array}$ \\
\hline 5. & $\begin{array}{l}\text { Lack of small } \\
\text { contractors' } \\
\text { involvement }\end{array}$ & $\begin{array}{l}\text { Small contractors are familiar with } \\
\text { conventional method and and addition } \\
\text { to this, due to lack of financial backup, } \\
\text { they are unable to set their own } \\
\text { manufacturing plant. }\end{array}$ & $\begin{array}{l}\text { Haroon et al, 2009; } \\
\text { Rahman \& Omar, } \\
2006\end{array}$ \\
\hline 6. & $\begin{array}{l}\text { IBS as mass } \\
\text { construction } \\
\text { method }\end{array}$ & $\begin{array}{l}\text { It is always linked with poor quality } \\
\text { industrialised buildings built in 1960s. } \\
\text { Poor architecture and old prefab } \\
\text { buildings have negative impact on } \\
\text { public. }\end{array}$ & $\begin{array}{l}\text { Rahman \& Omar, } \\
2006\end{array}$ \\
\hline 7. & Technology & Machinery redundancy & $\begin{array}{l}\text { Mohammad et al., } \\
2016 \\
\end{array}$ \\
\hline 8. & $\begin{array}{l}\text { Lack of } \\
\text { Awareness }\end{array}$ & $\begin{array}{l}\text { Many architects and engineers are still } \\
\text { unaware of the essential elements of } \\
\text { IBS such as Modular co-ordination, } \\
\text { due to lack of awareness and incentive } \\
\text { from Government in promotion of IBS. }\end{array}$ & Haroon et al., 2009 \\
\hline 9. & $\begin{array}{l}\text { Lack of } \\
\text { Knowledge }\end{array}$ & $\begin{array}{l}\text { There is a lack of R\&D in new } \\
\text { building systems that use local } \\
\text { materials. }\end{array}$ & $\begin{array}{l}\text { Haroon et al., } \\
\text { 2009; Rahman \& } \\
\text { Omar, } 2006 \\
\end{array}$ \\
\hline 10. & $\begin{array}{l}\text { Lack of } \\
\text { Scientific } \\
\text { Information }\end{array}$ & $\begin{array}{l}\text { Insufficient evidence to prove the } \\
\text { benefits of IBS, thus, due to lack of } \\
\text { scientific information the } \\
\text { implementation of IBS is delayed. }\end{array}$ & Badir et al., 2002 \\
\hline
\end{tabular}


Asiah Abdul Rahim \& Sara Latif Qureshi

A Review of IBS Implementation in Malaysia and Singapore

\section{CONCLUSION AND RECOMMENDATIONS}

The benefits of IBS are well-documented. However, the pace in the implementation of IBS in construction industry of Malaysia appears to be slower than expected. Based on the literature review, the advantages would give added values to the application of IBS instead of the barriers. These barriers are due to negative perceptions which can be overcome with the support of the government as well as the industry itself. IBS is no doubt, suitable for building functions that require mass production such as housing. The off-site construction has fast time frames, so this may be applied to the projects which have typical floors, which need more standardized and uniform design solutions. It provides neater and cleaner sites. Moreover, the IBS needs to be continuously improved with regards to quality, productivity, labour, safety, research invention and inferior working conditions. On the other hand, the universities having the faculty of Built Environment, for example, Architecture, Structural Engineering and Civil Engineering, should emphasize and promote the awareness and knowledge of Industrialised Building System (IBS). This would reduce the negative perceptions of IBS and subsequently increase the willingness to adopt IBS in construction industry.

\section{REFERENCES}

Abdullah. M. R., \& Egbu, C. (2009). IBS in Malaysia: Issues for research in a changing financial and property market. BuHu 9th IPGRC: Salford, UK, 15-25.

Ahadzie, D. K., Proverbs, D. G., \& Olomolaiye, P. (2008). Model for predicting the performance of project managers in mass house building projects. JCEM, American Society of Civil Engineers, 134(8), 618-629.

Aziz, S. N., \& Rauzan, N. F. (2003). IBS Survey 2003: Survey on the usage of industrialized building systems (IBS) in Malaysian construction industry. Kuala Lumpur: CIDB.

Azman, M. N. A., Ahamad, M. S. S., \& Hanafi, M. H. (2010). The common approach in off-site construction industry. Australian Journal of Basic and Applied Sciences, 4(9), 4478-4482.

Azman, M. N. A., Majid, T. A., Ahamad, M. S. S., \& Hanafi, M. H. (2011). A study on the trend of the use of IBS components and the setting UP of IBS manufacturing factories in the Malaysian construction industry. Malaysian Construction Research Journal 9(2), 18-30.

Badir, Y. F., Kadir, M. R. A., \& Hasim, S. (2002). Industrialized building system construction in Malaysia. Journal of Architectural Engineering, 8(1), 19-23.

BCA (2015). Circular on amendments to building control (buildability and productivity) (APPBCA-2015-13). Singapore: Author.

Bernama (2006). Local construction industry urged to use IBS. Retrieved from http://www.bernama.com/bernama/v3printable.php?id=185301 
PLANNING MALAYSIA

Journal of the Malaysia Institute of Planners (2018)

Bernama (2017, July 15). Malaysia's population climbs to 32 Million. Star Online. Retrieved

from

https://www.thestar.com.my/news/nation/2017/07/15/malaysias-population-

climbs-to-32-million/

Blismas, N., \& Wakefield, R. (2009) Concrete prefabricated housing via advances in systems technologies: Development of a technology roadmap. Engineering Construction and Architectural Management, 17, 99-110.

Bing, L., Kwong, Y. W., \& Hau, K. J. (2001). Seismic behavior of connection between precast concrete beams. CSE Research Bulletin, 14.

Construction Industry Development Board [CIDB] (2003). Industrialized building system (IBS): Roadmap 2003-2010. Kuala Lumpur: CIDB Publication.

Construction Industry Development Board [CIDB] (2004). Dirty, difficult and dangerous? Simplify it use IBS. Available at www.cidb.gov.my/content.php

Construction Industry Development Board [CIDB] (2016). Industrialised building system: The path to enhanced productivity. Heights, 3.

Din, H. (1984). Industrialized building and its application in Malaysia. In Proceedings of Seminar on Prefabrication of Building Construction, Kuala Lumpur.

Gann, D. E. (1996). Construction as a manufacturing process? Similarities and differences between industrialized housing and car production in Japan. Construction Management and Economics, 14, 437-450.

Gardiner, J. (2008) Exploring prefabrication - International study of prefabrication within aerospace, shipbuilding, automotive and construction industries. 10.13140/RG.2.2.31808.94724.

Gibb, A.G.F. (2001). Standardization and pre-assembly- distinguishing myth from reality using case study research. Construction Management and Economics, 19, 307315.

Hamid, Z. A., Kamar, K. A. M., Zain, M. Z. M., Ghani, M. K., \& Rahim, A.H.A. (2008) Industrialized building system (IBS) in Malaysia: The current state and R\&D initiatives. MCRJ, CREAM 2(1), 1-11.

Haroon, N. A., Rahman, H. A., \& Hanid, M. (2009). A literature review of advantages and barriers to the implementation of industrialized building system (IBS) in construction industry. Malaysian Construction Research Journal, 4(1), 10-14.

HDB to expand use of prefabrication building methods in BTO projects. (2017, $\begin{array}{llll}\text { September } & 6 \text { ). } & \text { Retrieved }\end{array}$ http://www.channelnewsasia.com/news/singapore/hdb-to-expand-use-ofprefabrication-building-methods-in-bto-9189786.

Hussein, J. (2007). Industrialised building system: The challenges and way forward. In Construction Industry Research Achievements International Conference (CIRAIC 2007). Kuala Lumpur: CIDB. 
Asiah Abdul Rahim \& Sara Latif Qureshi

A Review of IBS Implementation in Malaysia and Singapore

Ismail, Z., \& Rahim, A. A. (2009, October). Implementing built environment research findings in developing countries - the case study of East and Southern Africa. International Symposium on Construction in Developing Economies: Commonalities among Diversities. October 5-7, 2009, Penang, Malaysia.

Jaillon, L., \& Poon, C. S. (2009). The evolution of prefabricated residential building systems in Hong Kong: A review of the public and the private sector. Automation in Construction, 18, 239-248.

Kamar, K. A. M., Alshawi, M., Hamid, Z.A., Nawi, M. N. N., Haron, A. T., \& Abdullah, M. R. (2009). Industrialized building system (IBS): Revisiting the issues on definition, classification and the degree of industrialization. In Construction Industry Research Achievements International Conference (CIRAIC 2007). Kuala Lumpur: CIDB.

Khalil, F. D. A. A., Aziz, F. N. A. A., Hassim, S., \& Jaafar, M. S. (2016). A Review on Industrialized Building System Issues in Malaysia. MATEC Web of Conferences, 47, 04019.

Koenigsberger, O. (1986) Third World housing policies since the 1950s. Habitat International, 10(3), 27-32.

Langston, C. A., \& Ding, G. K. C. (2011). Sustainable practices in the built environment. London: Routledge.

Lovell, H., \& Smith, S. J. (2010). Agencement in housing markets: The case of the UK construction industry, Geo-forum, 41, 457-468.

Malaysia Equity Research (2014). Construction IBS - Practical solution to rising costs. Kuala Lumpur: MIDF Amanah Investment Bank Berhad.

Marsono, A. K., Tap, M. M., Ching, N. S., \& Makhtar, A. M. (2006). Simulation of industrialized building system components production. In Proceedings of the 6th APSEC (pp. 87-96). Kuala Lumpur, Malaysia.

Mohammad, M. F., Baharin, A. S., Musa, M. F., \& Yusof, M. R. (2016). The potential application of IBS modular system in the construction of housing scheme in Malaysia. Procedia - Social and Behavioral Sciences, 222, 75-82.

NAHB Research Center (2002). Technology roadmap: Whole house and building process redesign (year one progress report). Washington, DC: PATH.

Ofori, G., (2000). Challenges of construction industries in developing countries: Lessons from various countries. Retrieved from https://www.irbnet.de/daten/iconda/CIB8937.pdf

Omar, Z. (2000). Malaysian construction industry, challenges and demand. Malaysian Structural Steel Association Convention Report. Kuala Lumpur, Malaysia.

Pan, W., Gibb, A. G. F., \& Dainty, A. R. J. (2012). Strategies for integrating the use of offsite production technologies in housebuilding. JCEM, 138(11), 1331-1340. 
PLANNING MALAYSIA

Journal of the Malaysia Institute of Planners (2018)

Preece, C., Pheng, L., Padfield, R., \& Papargyropoulou, E. (2011, June). Developing and marketing sustainable construction services, Management \& Innovation for a Sustainable Built Environment. June 20-23, 2011, Amsterdam, The Netherlands.

Rahim, A. A., \& Ismail, Z. (2011). IBS towards open building system in Malaysia. Kuala Lumpur, Malaysia: IIUM Press.

Rahim, A. A., Hamid, Z. A., Zen, I., Ismail, Z., \& Kamar, K. A. M. (2012). Adoptable housing of precast panel system in Malaysia. Procedia - Social and Behavioral Sciences, 50, 369-382.

Rahman, B. A., \& Omar, W. (2006) Issues and challenges in the implementation of industrialized building systems in Malaysia. In Proceedings of the $6^{\text {th }}$ APSEC. Kuala Lumpur, Malaysia.

Seik, F. T. (2001). Planning and design of Tampines, an award-winning high-rise, highdensity township in Singapore. Cities, 18(1), 33-42.

Singapore Department of Statistics (2017). Population Trends 2017. Singapore: Author.

Thanoon, W. A., Peng, L. W., Kadir, M. R. A., Jaafar, M. S., \& Salit, M. S. (2003). The experiences of Malaysia and other countries in industrialized building system. In International Conference on Industrialized Building Systems (pp. 255-261). Kuala Lumpur, Malaysia.

Thanoon, W. A., Peng, L. W., Kadir, M. R. A., Jaafar, M. S., \& Salit, M. S. (2003). The essential characteristics of industrialized building system. In International Conference on Industrialized Building Systems (pp. 283-295). Kuala Lumpur, Malaysia.

Warszawski, A. (1999). Industrialized building system: Prospect in Malaysia. In Proceedings of World Engineering Congress, Sarawak, Malaysia.

Yunus R., \& Yang, J. (2011). Sustainability criteria for Industrialized Building Systems (IBS) in Malaysia. Procedia Engineering, 14, 1590-1598.

Yunus, R. (2017, September 14). Ajiya engages learning institutions to spur ibs adoption. The Malaysian Reserve. Retrieved from https://themalaysianreserve.com/2017/09/14/ajiya-engages-learninginstitutions-spur-ibs-adoption/ 